\title{
ADAPTASI RETINA IKAN SELAR (SELAROIDES LEPTOLEPSIS) TERHADAP INTENSITAS CAHAYA LAMPU
}

\section{LIGHT ADAPTATION PROCESS OF RETINAL YELLOWSTRIPE SCAD (SELAROIDES LEPTOLEPSIS)}

\author{
Nur Lina M. Nabiu', Mulyono S. Baskoro², Zulkarnain ${ }^{2}$, Roza Yusfiandayani ${ }^{2}$ \\ ${ }^{1}$ Program Studi Teknologi Perikanan Laut, Sekolah Pascasarjana \\ ${ }^{2}$ Departemen Pemanfaatan Sumberdaya Perikanan, \\ Fakultas Perikanan dan Ilmu Kelautan, Institut Pertanian Bogor \\ Korespondensi: linamaratana18@gmail.com
}

\begin{abstract}
Selaroides sp is one of the most biggest potential fish in Indonesia. The fishermen cacth it by light fishing that until now the technology is still developed. The using of light for light fishing cwn't be apart from fish criteria, positive phototaxis. Retin become more important to assess the ability of fish adaptation, that it makes research about light adaptation on fish retina is more needed to support the development of fishing technology. The research was conducted at Fish Health Laboratory, Department of Aquaculture, Fisheries and Marine Science Faculty, Bogor Agricultural University, observe adaptation of fish retina with histology method. Light intensity for this research are 10 lux, 20 lux, 35 lux and 50 lux with 2 different colors of light, blue and white. Results shows thst the con cells always move-in line- with the the increasing of light intensity. But the increasing of con cells movement from Retinal Pigment Epithelium to Outer Limitting Membrane, for every colors are different. It shows that Selaroides leptolepsis is sensitive to light colors for almost all intensity treatment with ratio about 79\%-90\%. Selaroides leptolepsis give more reaction to the low ilumination because the ratio get maximum at 10 lux-35 lux. It can be affected by the original environment of Selaroides leptolepsis that belong to pelagic so that it doesn't need high ilumination.
\end{abstract}

Keyword: adaptation, light fishing, retina, Selaroides leptolesis

\begin{abstract}
ABSTRAK
Potensi ikan selar merupakan salah satu potensi ikan pelagis yang cukup besar di Indonesia. Nelayan banyak menangkap ikan selar melalui light fishing yang hingga saat ini masih terus dikembangkan teknologinya. Penggunaan cahaya tidak dapat terlepas dari sifat fototaksis positif yang dimiliki ikan. Peranan retina pada mata ikan menjadi penting dalam melihat kemampuan adaptasi ikan, sehingga diperlukan penelitian yang lebih banyak mengenai adaptasi retina ikan pada ikan hasil tangkapan light fishing guna menunjang pengembangan teknologi penangkapan. Penelitian ikan selar ini dilakukan di Laboratorium Kesehatan Ikan, Departemen Budidaya Perikanan, IPB untuk pengamatan retina ikan melalui metode histologi sehingga dapat dilihat rasio penjuluran sel kon mata ikan pada setiap intensitas cahaya, yaitu 10 lux, 20 lux, 35 lux dan 50 lux dengan dua warna cahaya, yaitu putih dan biru. Dari hasil penelitian dapat disimpulkan bahwa pergerakan sel kon tetap terjadi seiring dengan peningkatan intensitas cahaya yang dipaparkan. Akan tetapi peningkatan pergerakan sel kon menuju membran pembatas luar untuk tiap warna cahaya berbeda. Pengaruh warna cahaya pada intensitas yang berbeda didapatkan bahwa ikan selar ini sensitif terhadap warna cahaya putih dan biru pada hampir semua intensitas yang diujicoba dengan kisaran penjuluran antara 79\%-90\%. Ikan selar lebih cepat bereaksi pada cahaya dengan iluminasi rendah karena penjuluran ikan lebih maksimal terjadi pada pemaparan 10 lux hingga 35 lux. Hal ini dapat disebabkan oleh tempat hidup ikan selar yang tergolong pelagik sehingga ikan selar tidak memerlukan iluminasi dan cahaya dengan panjang gelombang yang tinggi.
\end{abstract}

Kata kunci: adaptasi, ikan selar, light fishing, retina 


\section{PENDAHULUAN}

Sumberdaya ikan pelagis kecil di Indonesia diduga merupakan salah satu sumberdaya yang paling melimpah. Penyebarannya merata di perairan Indonesia, namun ada beberapa yang dijadikan sentra daerah penyebaran, seperti Lemuru (Sardinella longiceps) banyak tertangkap di Bali, Makassar, Ambon dan Laut Jawa, Kembung Lelaki (Rastrelliger kanagurta) di Selat Malaka dan Kalimantan, Kembung Perempuan (Rastrelliger neglectus) di Sumatera Barat, Tapanuli dan Kalimantan Barat, serta selar (Selaroides leptolepsis) di Teluk Jakarta (Sudirman et al. 2003).

Ikan selar adalah salah satu ikan yang banyak dimanfaatkan masyarakat baik dalam bentuk segar maupun olahan, sehingga banyak nelayan yang menjadikan ikan selar sebagai target tangkapan utama. Nelayan Teluk Jakarta menangkap ikan selar dengan menggunakan pukat pantai, pukat cincin, bagan, jaring insang, dan sero. Alat tangkap tersebut beberapa menggunakan alat bantu cahaya dalam proses penangkapannya (Sharfina et al. 2014).

Cahaya merupakan alat bantu untuk menarik dan mengumpulkan ikan ke daerah penangkapan (catchable area), dimana selanjutnya ikan dapat ditangkap. Sebagian besar nelayan hanya menggunakan cahaya warna putih dalam melakukan proses penangkapan ikan, umumnya hanya berpedoman pada pengalaman dan insting bahwa ikan tertarik oleh cahaya. Hal ini telah dilakukan selama bertahun-tahun tanpa didukung oleh kajian-kajian ilmiah (Utami 2006).

Penelitian tentang sensitivitas spektrum maksimum terhadap retina mata ikan telah dilakukan oleh beberapa peneliti misalnya yellowfin tuna, bigeye tuna, dan marlin yang sensitif pada panjang gelombang antara 458-492 nm (Kawamura et al. 1981). Selain itu, Zilanov (1968) mengemukakan bahwa Atlantic sauri sangat cepat tertarik dengan cahaya lampu dan mulai tertarik kepada cahaya sejak lampu dinyalakan antara 1 sampai 5 menit. Aktivitas makan Hoplosternum littorale dipengaruhi oleh warna cahaya biru dan merah (Boujard et al. 1992). Perkembangan ketajaman penglihatan red sea bream (Pagrus Major) (Shiobara et al. 1998), karakteristik histologi dan perkembangan retina pada Japanese sardine (Sardinos melanotictus) (Matsuoka 1999), dan fisiologi penglihatan Japanese whitting (Sillago japonica) (Purbayanto et al. 2001).

bahwa tiap spesies ikan mampu mengabsorbsi panjang gelombang tertentu secara maksimal oleh pigmen penglihatan (photo pigment). Aktivitas ikan dipengaruhi oleh lingkungannya dan cahaya pada umumnya menjadi faktor utama (Boujard et al. 1992). Terdapat beberapa faktor yang menyebabkan ikan dapat diarahkan atau dikumpulkan pada suatu area tertentu, salah satunya adalah ikan tertarik oleh cahaya karena adanya sifat fototaksis.

Faktor-faktor yang mempengaruhi adaptasi retina mata ikan adalah warna cahaya, intensitas cahaya dan lama waktu pemaparan. Hal ini dapat dilihat dari tingkatan adaptasi mata ikan terhadap intensitas cahaya. Terjadinya tingkatan adaptasi mataikan atau respon ikan terhadap cahaya ditandai dengan naiknya sel kon (cone cell) yang terdapat pada retina mata ikan (Gunarso 1985). Sel kon yang terdapat di dalam retina ikan bertanggung jawab pada penglihatan terhadap warna (color vision) (Tamura 1957). Menurut beberapa teori mata ikan mempunyai struktur yang sama seperti mata manusia dan mempunyai kemampuan untuk membedakan warna, artinya terdapat kemungkinan bahwa dari kemampuan ikan membedakan warna tersebut maka ikan pun cenderung akan menyukai warna-warna tertentu pada lingkungannya. Oleh sebab itu, penelitian tentang mata ikan khususnya mengenai preferensi ikan tersebut terhadap warna cahaya tertentu dengan intensitas yang berbeda sangat penting untuk dilakukan, dengan mengetahui pola tingkah laku ikan terhadap warna cahaya tertentu dan adaptasi retina mata ikan terhadap cahaya, maka taktik serta metode penangkapan ikan dapat direncanakan untuk mengoptimalkan operasi penangkapan.

\section{METODE PENELITIAN}

Penelitian dilakukan di Laboratorium Tingkah Laku Ikan Sekolah Tinggi Perikanan di Banten untuk pengamatan tingkah laku ikan dan Laboratorium Kesehatan Ikan, Departemen Budidaya Perikanan, IPB untuk pengamatan retina ikan selama kurang 
lebih satu bulan.

Peralatan yang digunakan dalam penelitian ini meliputi:

1. Bak pengamatan tingkah laku ikan

2. Data sheet dan alat tulis, untuk mencatat hasil pengamatan tingkah laku ikan

3. Lux meter

4. Tabung sampel untuk sampel retina ikan

5. Ember untuk perlakuan ikan

6. Lampu putih dan biru

7. Alat bedah

8. Larutan bouink dan alkohol $70 \%$

Perlakuan yang diujicobakan dalam penelitian ini adalah tingkat iluminasi cahaya yang diukur pada permukaan air dengan lux meter pada ikan sampel yaitu ikan selar (Selaroides leptolepsis). Ikan sampel merupakan sampel hidup dari alat tangkap sero di wilayah perairan Karangantu, Banten, dan ditransportasikan ke bak percobaan laboratorium. Perlakuan iluminasi cahaya dibedakan menjadi empat perlakuan, yaitu:

a. 50 Lux;

b. 35 Lux;

c. 20 Lux; dan

d. 10 Lux

Ikan diadaptasi di bak percobaan selama beberapa hari sebelum diberi perlakuan. Penelitian dilakukan pada malam hari agar ikan tidak terpengaruh oleh kondisi lingkungan, terutama cahaya matahari, dan diharapkan hanya akan fokus pada cahaya lampu penelitian. Ikan uji diletakkan dalam ember yang telah diisi air dan dibiarkan dalam kondisi tanpa cahaya selama setengah jam, kemudian lampu atas dinyalakan dan ikan disinari oleh cahaya lampu selama setengah jam pula. Proses pemaparan cahaya lampu pada ikan dapat dilihat pada Gambar 1.

Pengaruh cahaya pada retina ikan dapat diamati dengan melihat gerakan cone pada mata ikan sampel melalui metode histologi. Sampel mata ikan diambil dari masing-masing dua individu untuk setiap spesies ikan percobaan. Urutan perlakuan histologi adalah sebagai berikut (Fitri 2008):

a. Fiksasi (fixation)

b. Dehidrasi (Dehydration)

c. Penjernihan (Clearing)

d. Infiltrasi (Infiltration)

e. Penanaman Jaringan (Embedding) dan Blocking

f. Penyayatan (Section) dan Peletakkan pada Gelas Obyek

g. Pewarnaan (Staining) dan Mounting

Rasio adaptasi retina diperoleh dari nilai indeks cone, dihitung berdasarkan pergerakan cone. Ilustrasi perhitunggan rasio dapat dilihat melalui Gambar 2.

Formula yang digunakan adalah sebagai berikut (Sudirman 2003):

$$
\text { Cone indeks }(C \%)=C^{\prime} / \mathrm{A} \times 100
$$

C' : Jarak dari Retinal Pigmen Epithelium (RPE) ke pusat cone

A : Jarak dari RPE ke outer limiting membrane

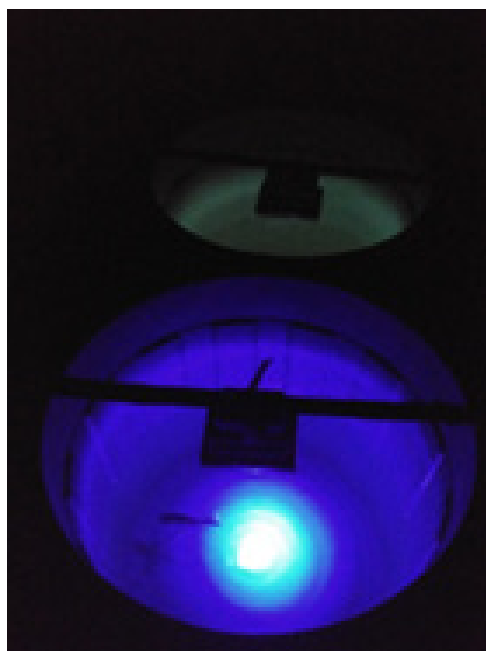

Gambar 1. Proses penyinaran ikan sampel di dalam ember perlakuan selama setengah jam 

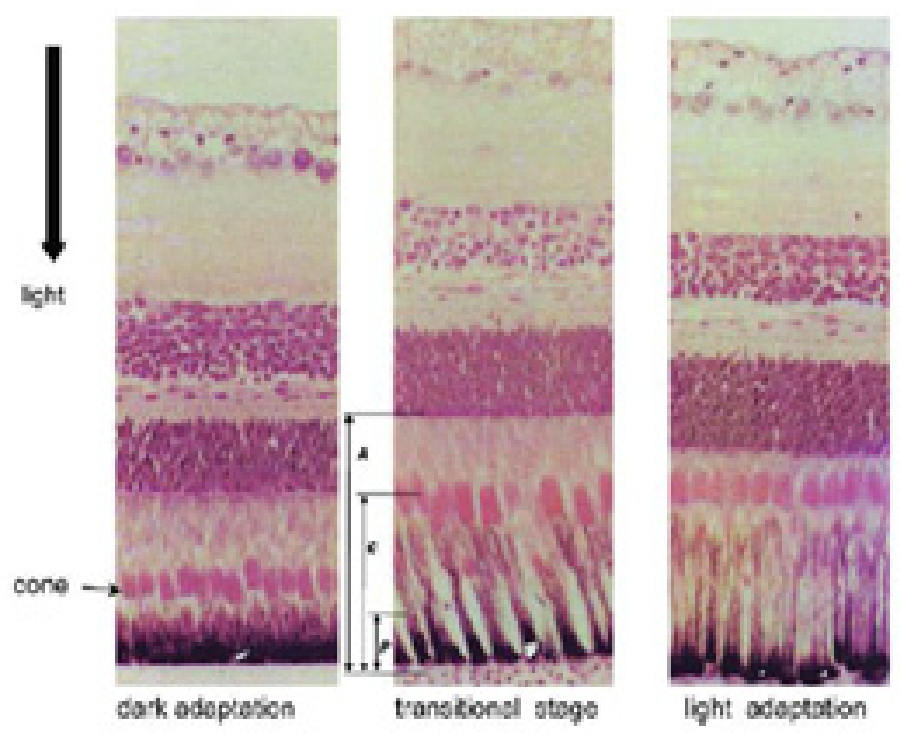

Gambar 2. Ilustrasi perhitungan nilai indeks kon

\section{HASIL DAN PEMBAHASAN}

Hasil penelitian pengaruh intensitas warna cahaya terhadap adaptasi retina mata selar (Selaroides leptolepsis), melalui proses adaptasi pada percobaan skala laboratorium dengan analisis histologi didapatkan bahwa pergerakan sel kon tetap terjadi seiring dengan peningkatan intensitas cahaya yang dipaparkan, akan tetapi peningkatan pergerakan sel kon menuju membran pembatas luar untuk tiap warna cahaya berbeda. Kuantitas dan kualitas cahaya yang digunakan akan mempengaruhi tingkah laku ikan terhadap cahaya, dimana mata ikan bereaksi selektif terhadap perbedaan spektrum (Nikonorov 1975).

Menurut Fujaya (2002), ikan memiliki kepekaan terhadap intensitas cahaya dan panjang gelombang tertentu. Pengenalan warna cahaya tersebut oleh ikan berlangsung sangat cepat yaitu sekitar 10-20 detik. Sensitivitas retina terhadap warna cahaya tergantung dari pigmen yang terdapat pada sel kon dan sel rod.

Menurut Fujaya (2002) seperti halnya pada semua hewan vertebrata, ukuran sel kon (sel kerucut) menunjukkan kesensitifitasan retina terhadap spektrum cahaya. Sel kerucut pendek sensitif terhadap gelombang cahaya pendek sedangkan sel kerucut panjang sensitif terhadap gelombang cahaya terpanjang. Sel kon tersebut selanjutnya dihitung kon indeksnya untuk mengetahui rasio atau perbandingan pergerakan panjang sel kon antar intensitas yang berbeda.

Pergerakan sel kon pada cahaya putih menunjukkan bahwa sel kon telah mengalami kenaikan index con tertinggi pada ikan sampel 1 sebesar $90 \%$ dan pigment index sebesar $76 \%$ pada pemaparan 10 lux. Pada pemaparan lux yang lebih besar, index con dan pigment index cenderung turun, walaupun terjadi kenaikan pada lux yang lebih tinggi di beberapa sampel, terutama pada ikan yang mendapat paparan cahaya berwarna biru. Hal tersebut bisa terjadi tergantung oleh kondisi fisik ikan. Hasil analisis con index dan pigment index pada ikan selar (Selaroides leptolepsis) dapat dilihat pada Tabel 1 .

Pengaruh warna cahaya pada intensitas yang berbeda didapatkan bahwa jenis ikan ini sensitif terhadap warna cahaya putih dan biru pada hampir semua intensitas yang diujicoba dengan kisaran penjuluran antara 79\%-90\%. Hal tersebut terlihat dari data analisis con index dan pigment index (Tabel 1). Berdasarkan hasil penelitian, dapat dilihat juga bahwa ikan selar lebih cepat bereaksi pada cahaya dengan iluminasi rendah karena penjuluran ikan lebih maksimal terjadi pada pemaparan 10 lux hingga 35 lux. Hal ini dapat disebabkan oleh tempat hidup ikan selar yang tergolong pelagik sehingga ikan selar tidak memerlukan iluminasi dan cahaya dengan panjang gelombang yang tinggi. 
Tabel 1. Hasil analisis con index dan pigment index pada ikan selar (Selaroides leptolepsis)

\begin{tabular}{|c|c|c|c|c|}
\hline Warna Cahaya & Sampel & Lux & Con Index (\%) & Pigment Index (\%) \\
\hline \multirow{8}{*}{ Putih } & \multirow{4}{*}{1} & 10 & 90 & 76 \\
\hline & & 20 & 81 & 73 \\
\hline & & 35 & 86 & 74 \\
\hline & & 50 & 88 & 74 \\
\hline & \multirow{4}{*}{2} & 10 & 80 & 70 \\
\hline & & 20 & 73 & 63 \\
\hline & & 35 & 84 & 76 \\
\hline & & 50 & 77 & 67 \\
\hline \multirow{8}{*}{ Biru } & \multirow{4}{*}{1} & 10 & 80 & 70 \\
\hline & & 20 & 86 & 78 \\
\hline & & 35 & 90 & 80 \\
\hline & & 50 & 79 & 72 \\
\hline & \multirow{4}{*}{2} & 10 & 83 & 73 \\
\hline & & 20 & 85 & 67 \\
\hline & & 35 & 83 & 63 \\
\hline & & 50 & 89 & 75 \\
\hline
\end{tabular}

\section{KESIMPULAN DAN SARAN}

\section{Kesimpulam}

Pergerakan sel kon tetap terjadi seiring dengan peningkatan intensitas cahaya yang dipaparkan. Akan tetapi peningkatan pergerakan sel kon menuju membran pembatas luar untuk tiap warna cahaya berbeda. Pengaruh warna cahaya pada intensitas yang berbeda didapatkan bahwa jenis ikan ini sensitif terhadap warna cahaya putih dan biru pada hampir semua intensitas yang diujicoba dengan kisaran penjuluran antara 79\%-90\%. Dapat dilihat juga bahwa ikan selar lebih cepat bereaksi pada cahaya dengan iluminasi rendah karena penjuluran ikan lebih maksimal terjadi pada pemaparan 10 lux hingga 35 lux.

\section{Saran}

Hasil penelitian terkait tingkah laku ikan Selaroides leptolesis yang telah dilakukan masih memerlukan penelitian lebih lanjut dengan menggunakan warna dan intensitas cahaya yang lebih bervariasi. Warna putih yang digunakan selama penelitian merupakan warna yang cukup banyak digunakan oleh para nelayan sementara warna biru merupakan satu warna pembanding. Oleh karena itu jika dalam penelitian selanjutnya warna cahaya yang digunakan untuk pembanding lebih bervariasi, maka tingkah laku ikan Selaroides leptolesis dapat dianalisis lebih jauh, dapat menambah referensi tingkah laku ikan dan referensi dasar pengembangan teknologi penangkapan ikan, khususnya perikanan lampu (light fishing)

\section{DAFTAR PUSTAKA}

Boujard T. Yann M. \& Pierre L. 1992. Diel cycles in Hoplosternum littorale: entrainment of feeding activity by low intensity colored light. Kluwer Academic Publishers. Netherlands: 301- $309 \mathrm{hlm}$.

Fitri ADP. 2008. Respons Penglihatan dan Penciuman Ikan Kerapu terhadap Umpan Terkait dengan Efektivitas Penangkapan. [Disertasi]. Institut Pertanian Bogor: Bogor

Fujaya Y. 2002. Fisiologi Ikan. Dasar Pengembangan Teknologi Perikanan. Proyek Peningkatan Penelitian Pendidikan Tinggi Departemen Pendidikan Nasional. 146 hlm

Kawamura G, W. Nishimura, S. Ueda and 
T. Nishi. 1981. Vision in Tunas and Marlins. Mem. Kagoshima.Univ. Res. Center S.Pac., Vol 2.No. 1.p:4-26.

Nikonorov IV. 1975. Interaction of Fishing Gear With Fish Aggregations. Keter Publishing House. Jerusalem Ltd. Israel $216 \mathrm{p}$.

Purbayanto A, Akiyama S, Arimoto T. 2001. Visual and Swimming Physiology of Japanese Whitting in Relation to The Capture Process of Sweeping Trammel Net. Di dalam: O. Carman et al., editor. Proceeding of the 4th JSPS International Seminar on Fisheries Science in Tropical Area. Tokyo University. Tokyo. International JSPS Project. Vol 10:151-155.

Sharfina Maizan et al. 2014. Potensi Lestari Ikan Selar Kuning (Selaroides leptolepsis) di Perairan Selat Sunda. Marine Fisheries Journal, Vol. 5 No. 1: 101-108.

Shiobara Y; Akiyama S, Arimoto T. 1998. Development Changes in The Visual Acuity of Red Sea (Pagrus major). Journal Fisheries Science. Vol. 64 No. 6 Departement of Marine Science and Technology. Tokyo University of
Fisheries. Tokyo. Japan. Pp: 944947.

Sudirman et al., 2003. Adaptasi Retina Mata Ikan Layang (Decapterus ruselli) Terhadap Cahaya dalam Proses Penangkapan pada Bagan Rambo di Selat Makassar. Jurnal Ilmu-Ilmu Perairan dan Perikanan Indonesia. Vol.10: 85-92.

Tamura, T. 1957. A Study of Visual Perception in Fish, Especially on Resolving Power and Accomodation. Bulletin of The Japanese Society of Scientific Fisheries. Vol 22, No.9. Fisheries Institute, Faculty of Agriculture, Japan. p: 536-557.

Utami Eva. 2006. Analisis Respons Tingkah Laku Ikan Pepetek (Secutor insidiator) Terhadap Intensitas Cahaya Berwarna. [Tesis]. Institut Pertanian Bogor: Bogor.

Zilanov K. 1968. Behaviour of Atlantik Sauri \& Snipefish in an illuminated zone in the north Atlantik Ocean. In fish behaviour \& fishing techniques Ed. By A.P. Alexseev. Murmanks, PINRO:p 146-157 